\title{
FORMATION OF THE CASHLESS ECONOMY IN UKRAINE AND IN THE WORLD
}

\author{
Anna Oleshko' \\ University of State Fiscal Service of Ukraine, Ukraine \\ Olena Tymoshenko² \\ Kyiv National University of Culture and Arts, Ukraine \\ Olena Trokhymets ${ }^{3}$ \\ Classic Private University, Ukraine
}

\begin{abstract}
The purpose of the paper is to study the trends in the development of the Cashless Global Economy and the prospects for the formation of the Cashless Economy of Ukraine. Methodology. The survey is based on the economic analysis of indicators of the number of debit and credit cards, the use of contactless payments, the spread of payments through mobile devices, and the volume of cashless transactions. The targeted indicator (target) of the cashless payments in Ukraine in 2020 and the share of cash in GDP will be no less than the average meaning in European Union. Results of the survey showed the identification of advantages and threats of the cashless economy and in the formation of the digitalization development activities. Practical implications. Proposals for the development of cashless payments can be implemented in the monetary policy of Ukraine. Value/originality. Increase in cashless payments in the economy, in the payment for goods and services, e-commerce, consumer crediting, social payments, pensions, and subsidies will lead to economic growth increase and integration processes in Ukraine.
\end{abstract}

Key words: Cashless Global Economy, Cashless Economy, monetary policy, e-money, digital currency.

JEL Classification: E51, E52, F65, G15

\section{Introduction}

A key transformation in the global money and credit market is the transition to innovative cashless money, the refusal from cash payments, and thus, construction of Cashless Global Economy. Formation of a cashless society requires some time and is determined by historical preconditions (Batiz-Lazo, Efthymiou, 2016).

Leading countries receive additional drivers of economic growth and impact on the countries with emerging markets in the implementation of cashless payments. The influence of highly developed countries on the formation of the cashless economy in emerging and developing countries is multidirectional. On the one hand, emerging market countries gain an access to innovative money market technologies and expand their ability to participate in international payment systems. On the other hand - the rapid growth of highly developed countries leads to an increase in the gap in innovation and financial development between them and the countries with emerging markets.

In this context, it is important for Ukraine to speed up the process of transition to Cashless Economy and its further integration as an equal partner in international economic relations. The purpose of the paper is to study the trends in the development of the Cashless Global Economy and the prospects for the formation of the Cashless Economy of Ukraine. In order to identify the level of development of Cashless Economy, the following indicators are used: digitalization of the financial sphere, the number of debit and credit cards per person, the use of contactless payments, the spread of payments through mobile devices, and the volume of cashless transactions.

\footnotetext{
Corresponding author:

${ }^{1}$ Department of Financial Markets, University of State Fiscal Service of Ukraine.

E-mail: anna_oleshko@ukr.net

${ }^{2}$ Department of Economics, Kyiv National University of Culture and Arts.

E-mail: etymoshenko@i.ua

${ }^{3}$ Department of Economic Theory, National and International Economics, Classic Private University.

E-mail: yelena.trohim@gmail.com
} 


\section{World trends in Cashless Global Economy}

Cashless payments in the world market are growing rapidly: in 2015, their volume amounted to 1.66 trillion USD, which is $14 \%$ more than in 2014. In international cashless payments, the share of credit cards in 2015 reached 580 billion USD, and the share in the e-commerce market was $30 \%$.

According to the McKinsey\&Company results of the research, the correlation of cash and cashless payment in the world is 85 to 15 and the most successful is a cashless economy of South America with the largest contribution from Canada and the USA and Western Europe (Fig. 1).

The most successful countries in the Cashless Economy implementation in 2017 are Canada, Swiss, Britain, France, USA, China, Austria, Germany, Japan, and Russia. The number of payment cards in these countries is average 2 per person.

Cryptocurrency is an innovative financial instrument as a decentralized digital value, which has a cryptographic protection of the record. There are about a thousand types of cryptocurrency nowadays (their number is constantly changing), among which the most widely used are Bitcoin, Ethereum, Ripple, BitcoinCash, Litecoin, and others.

Innovative technologies in the financial system are based on innovations in the field of biometrics, artificial intelligence (or digital intelligence), cryptography, cloud computing, blockchain. Today there is a rapid development of financial and technological companies that are developing technological projects in the field of finance, mainly in the banking system - Fintech. The total investments in Fintech in 2010-2015 had grown four times and reached 19 billion USD, of which the main part was invested in the development of innovative products in the field of payments and credits. The largest amount of investment had attracted the USA 7.0 billion USD, UK - 1.8 billion USD, and China 1.6 billion USD. In general, these countries hold 73\% of the world's investment in Fintech.
The level of success in implementing the concept of the Cashless Economy is determined by the share of cash in the money circulation of the country. For this purpose, the ratio of cash to GDP is used. Based on this indicator, the most successful cashless economy development is observed in the highly developed countries - Canada (the share of cash in GDP is 3.8\%), the UK (3.6\%), Norway (1.9\%), Denmark (3.0\%), and Sweden (1.9\%). On the contrary, the share of cash in GDP in Ukraine is $17 \%$, Belarus - 19.7\%, Moldova - 15.7\%, Russia - 12.5\%. Assuming that in 2017, Sweden and Norway abandoned the turnover of cash denominated in national currency and turned to entire cashless payments. Denmark followed the same example.

The formation of the Cashless Economy is an inevitable process for all subjects of international economic relations (Fürst, 2017), and for Ukraine, it is an accelerating factor for European integration and economic growth.

\section{Prospects for the formation of the Cashless Economy in Ukraine}

The cashless economy transition program has begun in Ukraine, as well as in the whole world.

The purpose of the program is to ensure the gradual transition to cashless payments showing the following results in 2020:

- Share of cash in GDP - 7.5\%,

- Number of POS-terminals - 11 thousand units per 1 million people,

- Level of cashless payments - 55\%, also through the national payment system "Prostir" - 30\%.

Today in Ukraine, more than half (53\%) of cashless transactions are conducted on the Internet, in the developed countries of the EU this figure reaches 90 percent. Total number of payment cards in Ukraine exceeded the number of population and in 2017 it was more than 59.9 million cards (Fig. 2).

Credit cards are given mostly for salary projects together with debit cards. At the same time, the main

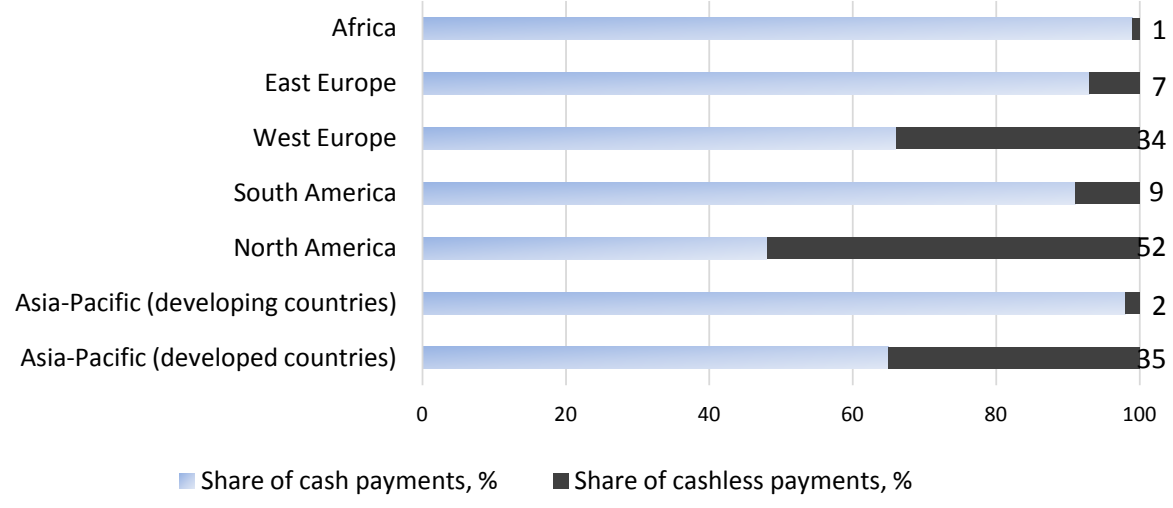

Fig. 1. The share of cashless payments in the world in 2015 


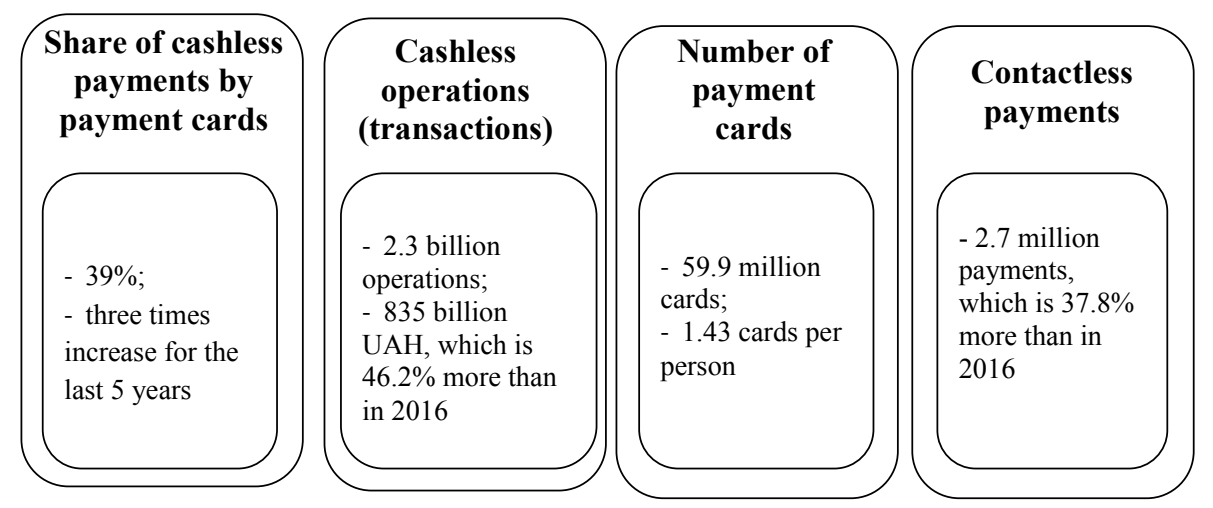

Fig. 2. The level of the Cashless Economy development in Ukraine

disadvantage of the short-term crediting to households by means of credit cards is the high commission compared to EU countries and some NIS countries. It is necessary to mention that since December 2015, the European Parliament has restricted the commission for credit cards at $0.3 \%$. On the contrary, in Ukraine, the commission for using credit cards is $1.4 \%$.

As for the cryptocurrency market development, in Ukraine, the concept "cryptocurrency" and regulation of transactions and operations with it do not subject to the legal regulation regime. Despite the existence of legally established practices of cryptocurrency use in the world (Japan, USA, Canada, Sweden, etc.), its complex legal nature does not allow it to be identified with any of the related concepts (cash, currency, currency value, legal instrument, electronic money, securities, money surrogate, etc.). Despite the absence of legal regulation, the amount of the Bitcoin market in Ukraine is $2.5 \%$ GDP. Besides, Ukraine is in the Top-4 countries with the cheapest Bitcoin mining: mining of one Bitcoin is 1852 USD ( $3 r d$ place - Uzbekistan (1788 USD), 2nd place - Trinidad and Tobago (1190 USD), 1st place - Venezuela (531 USD).

The introduction of the Cashless Economy requires purposeful state influence on the growth of cashless payments in the area of personal payments, real estate, payment for goods and services, e-commerce, transport, rent, tourism, wage payments, purchasing consumer goods, consumer crediting, rural economy crediting, government payments, social benefits, pensions, and subsidies.

\section{Advantages and Treats of the Cashless Economy}

The advantages of the Cashless Economy are the following:

- Cost reduction on money circulation maintenance;

- Cost reduction on money processing;
- Increased protection against robbery and money counterfeiting;

- Shadow economic sector reduction;

- Increasing the transparency of the formation of incomes and expenses of corporations, businesses, the sector of state administration and households;

- Reduction of operating expenses of banks, increase of their commission income and liquidity;

- Access to additional opportunities and services;

- The time of the transaction;

- The ability to pay in any currency and country of the world;

- Ease of use.

According to the opinion of those who do not support the total transition to cashless payments, the "electronization" of monetary and commodity operations will lead to the absolute control by global financial institutions (Banks mostly) over the economic and personal life of the planet population. Today banks possess full information about clients and are able to control their financial flows. At the beginning of the 20th century, R. Hilferding (1910) introduced the term "organized capitalism", in which banks set control over the economy and "organize" public life.

Another argument, which is not in favour of the Cashless Economy, is the presence and a steady growing tendency of cyber risks in digital technology (Wellisz, 2016). Cyber risks include targeted hacker attacks, software and hardware bookmarking equipment, espionage and informers, exploitation of vulnerabilities in obsolete equipment, etc.

The third warning to the formation of Cashless Economy is the spread of cryptocurrency. When deciding on the further introduction of cryptocurrency in the economy and finance, the following should be taken into account:

- the cryptocurrency is not tied to national states and, therefore, its ownership and circulation and turnover are not controlled; 
- the cryptocurrency doesn't serve "any socially useful function" (Stiglitz, 2017);

- the behaviour of bitcoin in the stock market corresponds to R. Schiller's theory of "financial bubbles" (Shiller, 2008);

- the cryptocurrency is often used to finance terrorism, criminal acts, and the shadow sector;

- the cryptocurrency transactions allow avoiding paying taxes;

- the cryptocurrency rate is formed under the influence of its demand/supply, that is, when absolute demand drops, it becomes insignificant;

- the cryptocurrency is not a measure of value that it does not express the price of the commodity;

- the cryptocurrency is not a means of payment, thus a number of purchases are insignificant;

- the cryptocurrency is concentrated in a small number of anonymous owners, which is a threat to absolutize their power in the money market;

- the cryptocurrency is subject to hacker attacks and theft.

However, despite the threats and warnings to the total transition to cashless payments, this trend is an objective reality, and in the upcoming years, the society will fully feel the changes caused by the new phase of the genesis of the Cashless Global Economy.

Thus, new technologies and informatisation became the main factors of exponential growth of the financial sector in the world. At the same time, banks carry the greatest costs for the acquisition and production of new technologies and innovative solutions.
The introduction of credit cards, Internet banking, mobile banking, mobile applications, and other innovations substantially modified the economic mechanism, the basic provisions of the monetary policy of national states and the lives of ordinary citizens.

\section{Conclusions}

The correlation of cash and cashless payments in different regions of the world and national states depends on the level of the development of democracy and economy, the level of openness of the economy, the share of the shadow sector and corruption, the level of penetration of the terminal network, mentality, culture, literacy of the population and motivation to cashless payments.

The introduction of electronic money, including cryptocurrency as a virtual currency, and alternative methods of payment, on the one hand, simplifies (makes more comfortable) economic life. On the other hand - it has some threats, firstly, the total control of banks and non-banking institutions over customers in connection with their possession of a significant amount of personal and biometric data, and secondly, the spread of cybercrime and the destruction of banking systems as a result of hacker attacks.

Digitalization of the social life and financial sphere is based on a fundamentally new philosophy of financial and economic relations between the population, business, and the state.

\section{References:}

Batiz-Lazo B., Efthymiou L. (2016) The Book of Payments: Historical and Contemporary Views on the Cashless Society. London: Palgrave Macmillan.

Fintech Investment Landscape. Innovate Finance. Retrieved from: https://new.innovatefinance.com/wp-content/ uploads/2018/02/final-2017-vc-investment-landscape_9feb.compressed.pdf_(accessed 27 March 2018).

Fürst H. (2017) A world becoming cashless. Description and analysis. Munich: GRIN Verlag.

Hilferding R. (2006) Finance Capital: A Study of the Latest Phase of Capitalist Development. London: Routledge.

Shiller J. R. (2008) How Today's Global Financial Crisis Happened, What to Do about It. - Princeton University Press. Stiglitz J. (2017) Bitcoin ought to be out lawed. World Economic Forum. Retrieved from: https://www.weforum.org/agenda/2017/11/joseph-stiglitz-bitcoin-ought-to-be-outlawed/ (accessed 27 March 2018).

Wellisz C. (2016) The Dark Side of Technology. Finance \& Development (electronic journal), Vol. 53, No. 3. pp. 14-17. Retrieved from: http://www.imf.org/external/pubs/ft/fandd/2016/09/pdf/wellisz.pdf (accessed 27 March 2018). 